\title{
Comparison of conventional microdiscectomy and sequestrectomy in ligamentum flavum preserved lumbar disc herniation surgery
}

\section{Ligamentum flavum korunarak yapılan lomber disk herniasyonu cerrahisinde klasik mikrodiskektomi ile sekestrektominin karşılaştırılması}

\author{
Barış Özöner ${ }^{1}$, Çağrı Canbolat ${ }^{2}$
}

Erzincan Binali Yildırm University Mengücek Gazi Training and Research Hospital, Department of Neurosurgery, Erzincan, Turkey

${ }^{2}$ Vezirköprü State Hospital, Neurosurgery Clinic, Samsun, Turkey

Corresponding author: Cağrı Canbolat, MD, Vezirköprü State Hospital, Neurosurgery Clinic, Samsun, Turkey

E-mail: cagricanbolat@gmail.com

Received/Accepted: July 20, 2019,/September 25, 2019

Conflict of interest: There is not a conflict of interest.

\section{SUMMARY}

Objective: Comparison of conventional microdiscectomy with sequestrectomy in lumbar disc herniation (LDH) surgery with ligamentum flavum (LF) preservation technique.

Method: Study design was approved by the local ethics committee. We retrospectively reviewed LDH 320 patients operated for disc pathologies in L3 - S1 levels in our clinic between June 2015 - June 2017. Two groups were formed in the study: sequestrectomy and conventional microdiscectomy. Demographic, operational and outcome data were compared between the groups.

Results: Sequestrectomy group included 71 patients and conventional microdiscectomy group included 60 patients. There was no statistically significant difference between the groups in terms of age, sex, comorbidities, smoking, body mass index, disc pathology level, operative complications, amount of bleeding, length of stay, disc recurrence and low back pain, radicular pain, quality of life, surgical success and satisfaction results. Satisfactory improvement rates were found in the conventional discectomy $(85 \%)$ and sequestrectomy group $(91.5 \%)$ in the mid-term follow-up. Operation time (mean $61.1 \mathrm{vs} 94.6 \mathrm{~min}$ ), and early postoperative opioid requirement $(14.1 \%$ vs $27.1 \%)$ were significantly lower in the sequestrectomy group.

Conclusions: In LDH surgery with LF preservative technique, satisfactory results were obtained with both methods with comparable. Recurrence rates and outcome. However, sequestrectomy is appropriate in cases without a wide annular defect due to the short operation time, low opioid requirement. Keywords: Disc herniation, flavum preserved, microdiscectomy, sequestrectomy
(D) Barış Özöner
(D) Çağrı Canbolat

ORCID IDs of the authors:

B.Ö. 0000-0003-0534-2766

Ç.C. $0000-0003-3576-5305$ 
Amaç: Ligamentum flavum (LF) korunarak yapılan lomber disk herniasyonu (LDH) cerrahisinde klasik mikrodiskektomi ile sekestrektomi yöntemlerinin karşılaştırılması.

Yöntem: Çalışma öncesi etik kurul onayı alındı. Kliniğimizde Haziran 2015 - Haziran 2017 arasında L3 - S1 aralığında disk patolojisi nedeniyle opere edilen LDH 320 hasta retrospektif olarak incelendi. Çalışmada sekestrektomi ve klasik mikrodiskektomi olmak üzere iki grup oluşturuldu. Gruplar arasında demografik, operasyonel ve sonuçsal verilerin karşılaştırması yapıldı.

Bulgular: Sekesrektomi grubuna 71, klasik mikrodiskektomi grubuna ise 60 olgu dahil edildi. Gruplar arasında yaş, cinsiyet, ek hastalık, sigara kullanımı, vücut kitle indeksi, disk patolojisi seviyesi, operatif komplikasyonlar, yatış süresi, kanama miktarı, disk rekürrensi ile bel ağrısı, radiküler ağrı, hayat kalitesi, operasyon bașarısı ve memnuniyet sonuçları açısından istatistiksel farklılık saptanmadı. Klasik diskektomi (\%85) ve sekestrektomi grubunda (\%91.5) orta dönemde tatmin edici oranlarda iyileşme oranları saptandı. Operasyon süresi (Ortalama 61.1 ve $94.6 \mathrm{dk}$ ) ve operasyon sonrası erken dönemde opioid ihtiyacı (\%14.1 ve \%27.1) sekestrektomi grubunda istatiksel anlamlı olarak daha az bulundu.

Sonuç: LF koruyucu yöntemle yapılan LDH cerrahisinde her iki yöntemle yüz güldürücü sonuçlar elde edilmiştir. Rekürrens ve sonuç verileri açısından iki yöntem arasında farklılık yoktur. Ancak cerrahi süre, ve opioid ihtiyacı azlığı nedeniyle anulus defektinin büyük olmadığı olgularda sekestrektomi yapılması uygun olacaktır.

Anahtar sözcükler: Disk hernisi, flavum koruyucu, mikrodiskektomi, sekestrektomi

\section{INTRODUCTION}

Lumbar disc herniation (LDH) create neurological deficits and give way to clinical findings, thus requiring surgical intervetion. ${ }^{1-3}$ Discs in this category are usually described to be either extrude (outside the disc gap boundary), and sequester (departed from the disc boundary by severance) in radiological imagery. ${ }^{4}$ Microdiscectomy is considered to be the conventional surgical methodology in this type of pathology.,6 Conversely, sequestrectomy is presented as the less invasive alternative to conventional microdiscectomy as it constitutes the removal of only the disc fragments, hence protecting the disc. ${ }^{7-}$ 9

During the LDH operation, ligamentum flavum (LF) is taken out to reach the neural structures and the disc pathologies, ${ }^{5,6}$ yet it is identified in the last couple of decades that this operation can be done while protecting the LF. ${ }^{10}$ Protecting the LF during the surgical procedure aims the reduction of long term epidural scars occurring after the surgery and nerve damage in case of a second surgical intervention. ${ }^{11}$

There are some studies comparing conventional microdiscectomy and sequestrectomy in the scientific literature $;^{7-9}$ however, there are no works comparing these two methods during a surgical procedure when the LF is protected. The aim of this study is to compare these two methods retrospectively.

\section{MATERIAL AND METHODS}

The protocol of the study was evaluated and approved by the Erzincan University Local Ethics Committee. Patients operated for LDH in our clinic between June 2015 - June 2017 were involved in this study. Indications for the LDH surgery were determined as three months of no response to the conventional treatment and sighting of clinical motor deficits. Following criteria were established for recruitment to the study: $18-65$ years old, a disc pathology between L3-S1, consistency of radiologically determined LDH pathology with the clinical findings, no prior history of spine surgery, and no history of trauma, cancer, and infection.

An informed consent form was taken from all the patients prior to the surgery. Surgical procedures were done with patient compliance in cases without medical and anatomical impediments under epidural anesthesia. In other cases, the proceedings were done under orotracheal general anesthesia. All surgical procedures were done under the Zeiss OPMI Vario / S88 operation microscope (Carl Zeiss Meditec, Jena, Germany, European Union) with microsurgical methods. Specific criteria were followed in choosing between conventional microdiscectomy or sequestrectomy methods: Sequestrectomy were decided in cases including sequester and extrude disc fragments with no apparent defect on annulus fibrosus after the removal of the fragments, defects under $4 \mathrm{~mm}$, and no new material emergence after irrigation of the defect with isotonic saline. On the other hand, microdiscectomy was decided in cases where the disc pathology is bulge, a distinct annular defect is larger than $4 \mathrm{~mm}$, and new material emergence after irrigation of the defect.

The surgical procedure was started with a skin incision of 15-20 mm. Lateralization of the muscles was done with subperiosteal dissection after perivertebral fascia incision. A Taylor retractor was used. Microlaminotomy was done on the 
inferior and superior laminae in the L3 - L4 and L4 - L5 levels depends on the herniation level. Then, LF was detached from the inferior and superior laminae. In the cases where the L5 - S1 interlaminar space was ample enough, LF was separated with the help of a dissector from the inferior lamina, and a curved curette from the superior lamina without microlamitomy. Lateral release of LF was performed using a $2 \mathrm{~mm}$ Kerrison rongeur. The nerve root under LF was relocated to the medial with the help of a root retractor after being detected with a microdissector. Extruded and sequestrated disc fragments detected at this stage and were removed with the help of microsurgical tools. Afterward, a choice between sequestrectomy and conventional microdiscectomy was made after an examination of the defect on annulus fibrous depends on the criteria which were explained before. The intervertebral disc space was not intervened during sequestrectomy. During conventional microdiscectomy, a tetragonal shaped anulotomy was made after the relocation of the nerve root to the medial. Then, the nuclear material found in the disk space was removed with curettage of endplates. In postoperative period, early mobilization (6 - 8 hours later) was made in all of the cases and a sitting ban (max. 15 minutes) was dictated for 15 days. Time of discharge arranged from 1 to 3 days depends on the condition of the patient. Patients were also called for medical examination 15 days, 3 months, 1 year and annually in the following years after the operation. To finalize the study, all patients were invited for a medical exam following the approval of the local ethical committee.

Demographical and radiological data from the patients before and after the operation was obtained from our hospital's electronic archive. Patient conclusion data was gathered from the clinical examination and query that was conducted during patients' visit to the hospital for the finalization of this study. Demographic data include patients' age, sex, tobacco usage, body mass index, medical history, and pathological disc levels. Data collected during the operation includes the amount of bleeding, operation length, and complications. Data collected after the operation contains the need for opioid administration and the length of stay in hospital. Lastly, outcome data consists of recurrence of the disk pathology, and an evaluation of quality of life from the status of back pain before and after the operation. Visual Analog Scale (VAS) was used for scoring of the pain, ${ }^{12}$ and the patients were asked to determine their pain by giving it a value between 0 - 10. Oswestry Disability Index was (ODI) was used to assess the quality of life. ${ }^{13}$ Patient satisfaction and the success of the operation was determined by using the Modified Macnab criteria. $^{14}$ In this classification, results are determined as "excellent" (complete recovery of symptoms), "good" (partial recovery of symptoms), "fair" (no change in symptoms), and "poor" (worsening of symptoms). Excellent and good results are considered as improvement, fair results are regarded as stable and poor results are considered to be a worsening. During the study, data was collected by two researchers independent from study. The reoperation in the same level for symptoms of LDH with radiologically coherent existence of a herniated disc was considered as recurrence.

Statistical analysis was performed with SPSS 20.0 (SPSS Inc., Chicago, IL, USA). Numerical variables were summarized as mean and median. Differences between the continues variables of groups were assessed by independent samples t-test and analysis of categorical variables was examined by the chi-square test. A value of $p<0.05$ was considered significant for all statistical analyses.

\section{RESULTS}

In total, 131 patients who underwent LDH surgery with LF preservation method were found to be consistent with the criteria of the study. Of these, 71 had sequestrectomy and 60 had conventional discectomy. The data about the group characteristics in which the two groups are compared are summarized in Table-1. There was no difference between the two groups in terms of age, gender distribution, smoking, medical history (type II diabetes mellitus, essential hypertension), and distribution of disc pathology. When the levels of disc pathologies were examined in sequestrectomy $(82.7 \%)$ and conventional microdiscectomy $(90 \%)$ groups, most of the disc pathologies were localized at L4 - L5 or L5 - S1 levels. 
Table 1: Characteristic data of the groups

\begin{tabular}{|c|c|c|c|}
\hline \multirow[b]{2}{*}{ Variables } & \multicolumn{2}{|c|}{ Groups } & \multirow[b]{2}{*}{$p$ value } \\
\hline & Sequestrectomy & $\begin{array}{c}\text { Conventional } \\
\text { Microdiscectomy }\end{array}$ & \\
\hline Number of cases & 71 & 60 & \\
\hline Age (years) & $49.1 \pm 10.9$ & $48.6 \pm 12.8$ & 0.809 \\
\hline Gender (woman/man) & $31(\% 43.6) / 40(\% 56.4)$ & $23(\% 38.3) / 37(\% 61.7)$ & 0.537 \\
\hline Body-mass index & $28.1 \pm 4.2$ & $27.2 \pm 3.9$ & 0.649 \\
\hline \multicolumn{4}{|l|}{ Medical history } \\
\hline Smoking & $29(\% 40.8)$ & $26(\% 43.3)$ & 0.773 \\
\hline Hypertension & $14(\% 19.7)$ & $17(\% 28.3)$ & 0.247 \\
\hline Diabetes Mellitus & $16(\% 22.5)$ & $13(\% 21.7)$ & 0.860 \\
\hline Disc level & & & 0.971 \\
\hline L3 - L4 & $8(\% 11.3)$ & $6(\% 10)$ & \\
\hline L4 - L5 & $33(\% 46.4)$ & $28(\% 46.7)$ & \\
\hline $\mathrm{L} 5-\mathrm{S} 1$ & $30(\% 42.3)$ & $26(\% 43.3)$ & \\
\hline
\end{tabular}

The data of both groups during and after the operation (until being discharged) is compared in Table 2. The operation time was significantly longer in the conventional microdiscectomy group $(94.6 \pm 22.3 \mathrm{~min})$ than in the sequestrectomy group $(61.1 \pm 11.4 \mathrm{~min})(\mathrm{p}<0.001)$. When the total amount of bleeding during operation was examined, less amount of bleeding was observed in the sequestrectomy group $(85.1 \pm 26.3 \mathrm{cc})$ than conventional microdiscectomy group $(91 \pm 27.5$ $\mathrm{cc})$. But there was no significant difference $(\mathrm{p}=$ 0.206). Concerning the complications during the operation, there was only one $(\% 1.4)$ case of complication in the sequestrectomy group and two $2(\% 3.3)$ cases of iatrogenic durotomy were seen in the conventional microdiscectomy group. Primary repair of the defect was performed in all cases and the defect was supported by fat graft. There was no need for re-operation in neither group due to bleeding or cerebrospinal fluid fistula. Postoperative follow-up indicated that there was only a single case of superficial infection in both groups which could be treated with appropriate antibiotherapy, but no deep infection was observed. When the two groups were combined, the number of smokers was $55(42 \%)$. And recurrence was found in $6(4.6 \%)$ cases in the series. Recurrence was observed in $2(2.8 \%)$ cases in the sequestrectomy group and $4(6.7 \%)$ cases in the conventional microdiscectomy group. Recurrence rate was higher in the conventional discectomy group; however, there was no statistically significant difference $(p=0.293)$. Out of them of these six cases, five patients were found to be smokers. In our series, there was a correlation between the recurrence of surgically treated LDH and smoking history $(p=0.035)$ independent of group comparison. In patients with recurrence, the meantime of such pathology was $15.3 \pm 7.1$ months after surgery. Four of the recurrent cases were operated in our clinic. Two patients preferred to be operated in external clinics. In our clinic, conventional microsurgical approach was performed for recurrent cases. In all four cases, no 
third intervention was required during the followup period. It was also learned that stabilization was achieved in the other two cases which were operated in external clinics. In the phone interviews conducted with the surgical teams performing the operations of two cases, it was found that there was no sign of instability but that the stabilization was the choice of the team performing the surgery. Regardless of the groups, recurrence was observed in 1 patient in L3 - L4, 2 patients in L4 - L5 and 3 patients in L5 - S1.

Table 2: Data of groups during and after the operation

\begin{tabular}{lccc}
\hline & \multicolumn{3}{c}{ Groups } \\
\cline { 2 - 3 } Variables & Sequestrectomy & $\begin{array}{c}\text { Conventional } \\
\text { Microdiscectomy }\end{array}$ & $p$ value \\
\hline Number of cases & 71 & 60 & $<0.001$ \\
\hline Operation time (min) & $61.1 \pm 11.4$ & $94.6 \pm 22.3$ & 0.206 \\
\hline Amount of bleeding (cc) & $85.1 \pm 26.3$ & $91 \pm 27.5$ & \\
\hline Complications & $1(\% 1.4)$ & $2(\% 3.3)$ & 0.463 \\
Duratomy & $1(\% 1.4)$ & $1(\% 1.7)$ & 0.904 \\
\hline Superficial infection & $10(\% 14.1)$ & $17(\% 25)$ & 0.044 \\
\hline Opioid recruitment & $1.85 \pm 0.96$ & $2.03 \pm 1.13$ & 0.171 \\
\hline Length of stay (days) & & & \\
\hline
\end{tabular}

The requirement for opioid usage in the early postoperative period was significantly less in the sequestrectomy group $(n=10,14.1 \%)$ than in the conventional microdiscectomy group $(\mathrm{n}=17$, $28.3 \%)(p=0.044)$. In addition, the duration of hospitalization was somewhat shorter in the sequestrectomy group (1.85 \pm 0.96 days $)$ than in the conventional microdiscectomy group $(2.03 \pm$ 1.13 days). However, this difference was not statistically significant $(\mathrm{p}=0.171)$.

The results of both groups are summarized in Table 3 . There was no significant difference between the sequestrectomy group (mean: $31.6 \pm 7.6$, range: $24-$ 48 months) and the conventional microdiscectomy group (mean: $33.3 \pm 7.9$, range: $24-48$ months) in terms of follow-up time. In our study, radicular and low back pain follow-up was performed with the VAS scoring. When the pain scores were compared, the severity of radicular pain in the preoperative period was similar in the sequestrectomy group $(9.1 \pm 1.2)$ and in the conventional discectomy group $(9.2 \pm 0.9)(\mathrm{p}=$
0.417). In addition, there was a significant decrease in the severity of the radicular pain in both groups. Postoperative pain scores should be given. When compared, there was no difference between the sequestrectomy group and the conventional microdiscectomy group in terms of postoperative follow-up radicular pain scores $(p=0.128)$, and the difference between preoperative and postoperative follow-up scores $(p=0.291)$. In terms of low back pain, the pain scores were lower in the sequestrectomy group $(6.9 \pm 2.7)$ than in the conventional microdiscectomy group $(7.6 \pm 2.8)$. However, there was no significant difference between the groups in terms of low back pain in the preoperative period $(\mathrm{p}=0.244)$. There was a significant improvement in back pain in both groups. Postoperative pain scores should be given. However, there was no significant difference between the two groups when the groups were compared in terms of postoperative low back pain scores $(p=0.257)$ and the difference between preoperative and postoperative follow-up scores ( $\mathrm{p}$ $=0.294$ ). 
Table 3: Outcome data of groups

\begin{tabular}{|c|c|c|c|}
\hline \multirow[b]{2}{*}{ Variables } & \multicolumn{2}{|c|}{ Groups } & \multirow[b]{2}{*}{$p$ value } \\
\hline & Sequestrectomy & $\begin{array}{c}\text { Conventional } \\
\text { Microdiscectomy }\end{array}$ & \\
\hline Number of cases & 71 & 60 & \\
\hline Follow-up ( months ) & $31.6 \pm 7.6$ & $33.3 \pm 7.9$ & 0.115 \\
\hline Disc recurrence & $2(\% 2.8)$ & $4(\% 6.7)$ & 0.293 \\
\hline \multicolumn{4}{|l|}{ Radicular pain } \\
\hline Pre-operation (VAS) & $9.1 \pm 1.2$ & $9.2 \pm 0.9$ & 0.417 \\
\hline End of follow-up (VAS) & $1.4 \pm 1.5$ & $1.9 \pm 2.4$ & 0.128 \\
\hline Differnce (VAS) & $7.7 \pm 2.1$ & $7.3 \pm 2.5$ & 0.291 \\
\hline \multicolumn{4}{|l|}{ Low back pain } \\
\hline Pre-operation (VAS) & $6.9 \pm 2.7$ & $7.6 \pm 2.8$ & 0.244 \\
\hline End of follow-up (VAS) & $1.9 \pm 2.1$ & $2.2 \pm 2.7$ & 0.257 \\
\hline Differnce (VAS) & $5 \pm 2.9$ & $5.4 \pm 3.6$ & 0.294 \\
\hline \multicolumn{4}{|l|}{ Quality of life } \\
\hline Pre-operation (ODI) & $80.5 \pm 12.9$ & $79.6 \pm 13.7$ & 0.382 \\
\hline End of follow-up (ODI) & $12.9 \pm 15.5$ & $13.7 \pm 13.2$ & 0.471 \\
\hline Differnce (ODI) & $66.6 \pm 19.1$ & $65.9 \pm 22.5$ & 0.443 \\
\hline Succes (Modified Macnab criteria) & & & 0.240 \\
\hline Improvement (excellent and good) & $65(\% 91.5)$ & $51(\% 85)$ & \\
\hline Stable & $6(\% 8.5)$ & $8(\% 13.3)$ & \\
\hline Worsened & & $1(\% 1.7)$ & \\
\hline
\end{tabular}

VAS: Visual Analog Skala, ODI: Oswestry Disability Index

Quality of life was assessed by Oswestry scale, and daily life activities were limited in the majority of the patients in the sequestrectomy group $(80.5 \pm$ 12.9) and the conventional microdiscectomy group (79.6 \pm 13.7). On the other hand, significant improvement was observed in terms of postoperative follow-up scores in the sequestrectomy group $(12.9 \pm 15.5)$ and conventional discectomy group $(13.7 \pm 13.2)$. There was no significant difference in preoperative $(\mathrm{p}=$ $0.382)$, in the end of follow-up $(p=0.471)$ and difference $(p=0.443)$ ODI scores between the groups. The success of the operation was performed using Modified Macnab Scoring according to the improvement of symptoms. According to this scoring, improvement was 
observed in $91.5 \%$ of sequestrectomy group and in $85 \%$ of conventional discectomy group. There was no significant difference between the two groups in terms of operation success $(\mathrm{p}=0.240)$.

\section{DISCUSSION}

The LF extends anatomically between the lower and upper bone lamina over the dura mater layer in the posterior segment of the spine. ${ }^{15}$ Due to this localization, it has effects on the spine dynamics and protection of the neural structures. ${ }^{16}$ In the classical definition of LDH surgery, following laminotomy LF tissue is excised before revealing the dural sac and neural roots. ${ }^{16} \mathrm{LF}$ preservation is possible by releasing of LF during laminotomy. LF preservation during LDH surgery reduces the occurrence of fibrosis in the epidural area in the postoperative period. ${ }^{17}$ This is due to the minimal damage to the standard anatomic structure during operation. In addition, spine dynamics would be less affected. Due to the small size of epidural fibrosis, the results of a second surgery may be expected to be better. In a study comparing LF preserved and LF non-preserved groups in cases where the second surgical intervention was required, surgical duration was shorter, bleeding amount and complication rate was lower, and the success of the operation was higher in LF preserved group. ${ }^{18}$ Consequently, these results encourage a reader to decide that LF preservation results in better anatomical outcomes in the lumbar spine after LDH surgery.

Many studies comparing sequestrectomy with conventional microdiscectomy have been previously made. ${ }^{7,8}$ However, there is no study that investigates whether LF preservation during surgery creates a difference in the comparison of these two methods. The difference in radiological and clinical outcomes of LF protection necessitates this study.

When demographic data are analyzed in our series, no difference was observed between the groups in age, gender, comorbidity, smoking and disc level distribution. However, the male / female ratio was higher in both groups (1.3 times higher in the sequestrectomy group and 1.6 times higher in the conventional discectomy group). In the social cross-sectional series, the rate of symptomatic LDH was found to be higher in women. ${ }^{19}$ The reason for the higher male ratio in our study was thought to be the fact that our patient population is from Erzincan-Gümüşhane region where the male participation in the agricultural labor force is higher.
It can be hypothesized that the total surgical duration of conventional microdiscectomy may be longer as it includes anulotomy and the removal of the intervertebral disc space when compared to sequestrectomy in which only fragment is removed, and the disc space is left untouched. The results of our series support this hypothesis. In addition, the majority of previous studies have shown that the surgical duration of sequestrectomy is significant shorter. ${ }^{20-23}$ In contrast, Shamji et al..$^{24}$ showed that there was no difference in total surgical length between two methods. However, it should be noted that in their study, two methods were applied by two different surgeons. ${ }^{24}$

It may be thought that shortening the duration of surgical intervention may decrease the amount of bleeding. However, according to the results of our study, although the surgery took less time in sequestrectomy, there was a decrease in blood loss; however, this difference was not significant. Similarly, in the literature, it was reported that there is no difference in the amount of bleeding between the two methods. ${ }^{7}$

Complications of LDH surgery include iatrogenic durotomy, wound infection, instability, neural injury, and hematoma. ${ }^{9}$ In our series, durotomy and superficial infection were observed in both groups. Upon a comparison of total complication rate, durotomy, and shallow infection rates, no difference was found between sequestrectomy and conventional microdiscectomy. In a meta-analysis, durotomy rates were reported to be $3.2 \%$ in traditional microdiscectomy and $2.2 \%$ in sequestrectomy, and the difference was not significant. ${ }^{7}$ In our series, these rates were 3.3\% and $1.4 \%$, respectively. The fact that these rates are consistent with the literature reveals that LF preserving surgery has no protective or enhancing effect on the possibility of dural tear development. In the same meta-analysis, infection rates were reported to be $2.6 \%$ in conventional microdiscectomy and $1.9 \%$ in sequestrectomy, and the difference was not significant. ${ }^{7}$ In our series, although deep surgical site infection was not detected, superficial wound infection was observed in rates of $1.7 \%$ and $1.4 \%$ respectively. The rates are slightly below the literature but do not differ. ${ }^{7,9}$

Since there is no intervention in the disc space during sequestrectomy, it can be thought that it is less invasive and there is less pain in the postoperative period in an operation with less tissue damage. In our study, a comparison was made in terms of the opioid requirement for this evaluation. The postoperative opioid requirement was found to be significantly less in the 
sequestrectomy group. Similarly, in previous studies, it was concluded that the amount of analgesic and opioid use was less in patients undergoing sequestrectomy. ${ }^{25,26}$

In terms of length of stay in the hospital, total time is reported as $0.9-6.4$ days in sequestrectomy and 1.17 - 6.9 days in conventional microdiscectomy. ${ }^{27-}$

29 In one publication, it was reported that sequestrectomy had a statistically significant shorter hospital stay with a difference of 0.5 days. ${ }^{27}$ In addition, the results suggest that there is no difference in terms of length of stay. In our series, the duration of hospitalization in sequestration (Mean: 1.85 days) was found to be shorter than that of conventional microdiscectomy (Mean: 2.03 days). However, the difference was not statistically significant.

A topic discussed in the literature on the choice of sequestrectomy and conventional microdiscectomy is the effect on recurrence. While some of the publications argue that there was no difference between sequestrectomy and conventional microdiscectomy in the middle term, ${ }^{25,27,28,30}$ there was also some studies suggesting that recurrence rate was higher in long-term sequestrectomy. ${ }^{29} \mathrm{In}$ our series, these rates are $2.8 \%$ in sequestrectomy, and $5.6 \%$ in conventional microdiscectomy. Recurrence rate was lower in the sequestrectomy group, but the difference was not statistically significant.

In our study, there was a significant improvement in symptoms in both groups postoperatively when evaluating radicular pain, and there was no difference between groups in terms of improvement and final pain scores. The results of many studies are consistent with our series. ${ }^{25,29,30}$ However, in a meta-analysis of the results of 4 studies, the results of sequestrectomy were found to be slightly better. ${ }^{7}$ In addition, in another metaanalysis, the results were found to be equal. ${ }^{9}$ In our study, foraminotomy was performed in both cases after pathological disc extraction, as such it was confirmed that the neural root was decompressed in both methods. It is also seen that in our series, postoperative pain is lower than studies without the application of foraminotomy. ${ }^{7,9}$ It is seen that radicular pain scores were found to be lower in another study where foraminotomy was applied than in the other publications. ${ }^{23}$ The reason for the reduction of postoperative pain may be foraminotomy itself.

When the two methods are compared in terms of low back pain, there are different results in the literature. In most analyses, both methods have reported significant improvement in low back pain postoperatively. In terms of pain results, one metaanalysis $^{7}$ found no difference between two methods, whereas another meta-analysis ${ }^{9}$ reported less pain in sequestrectomy. In one study, it was reported that there was more low back pain in the sequestrectomy group after 5 years of follow-up. ${ }^{29}$ In our series, there was a significant improvement in low back pain after the operation in both methods. In addition, there was no difference between low back pain, postoperative reduction, and outcome scores. These data reveal that the two methods, with LF protective technique, do not have superiority in terms of low back pain.

In our study, quality of life was evaluated using ODI. There was no difference between sequestroctomy and conventional microdiscectomy groups after over 30 months of follow-up. However, there are previous studies with different results. In a study performed with ODI, it was reported that the quality of life was worse in the sequestrectomy group in the 1 and 5year follow-up results. ${ }^{23}$ In contrast, another study observed that the effect of conventional microdiscectomy on the quality of life results was more negative according to the ODI scores after a two year follow-up. ${ }^{29}$

When the success of the operation and patient satisfaction were evaluated, it was found that high rates of improvement were observed in both groups in our series. In addition, there was no significant difference between the two groups with an average follow-up of over 30 months. In a meta-analysis, when the data of 6 studies are pooled, it is seen that the satisfaction rates of sequestrectomy were higher. ${ }^{7}$ In contrary to the literature, it can be said that the LF preserved surgery does not differ between the two methods.

Our study has several limitations. Firstly, due to the retrospective nature of the study, some of the outcome variables could not be analyzed. Despite having a sufficient number of patients, our series only includes surgical interventions performed by a single clinic and single surgeon. The results of our study should be controlled with prospective multi-center studies.

\section{CONCLUSION}

LF-preserved surgery of LDH offers promising results with sequestrectomy or conventional discectomy in the middle term. In sequestrectomy, shorter operation length and less postoperative opioid use are encountered. There was no difference in terms of recurrence and outcome. According to the results of our study, it is 
appropriate to perform sequestrectomy in selected cases.

\section{REFERENCES}

1. Grantham SA. Herniated lumbar disc. Am J Surg. 1952;83(4):531-537.

2. Vroomen PCAJ, De Krom MCTFM, Knottnerus JA. When does the patient with a disc herniation undergo lumbosacral discectomy? J Neurol Neurosurg Psychiatry. 2000;68(1):75-79

3. Heliövaara $M$, Knekt $P$, Aromaa A. Incidence and risk factors of herniated lumbar intervertebral disc or sciatica leading to hospitalization. J Chronic Dis. 1987;40(3):251-258.

4. Li Y, Fredrickson V, Resnick DK. How Should We Grade Lumbar Disc Herniation and Nerve Root Compression? A Systematic Review. Clin Orthop Relat Res. 2015;473(6):1896-1902.

5. Calina N, Serban D, Constantinescu A, DiGiorgio A, Tender G. Microdiscectomy. In: Minimally Invasive Spine Surgery Techniques. 2018. p. 5-21.

6. Koebbe CJ, Maroon JC, Abla A, El-Kadi H, Bost J. Lumbar microdiscectomy: a historical perspective and current technical considerations. Neurosurg Focus. 2002;13(2):E3

7. Ran J, Hu Y, Zheng Z, Zhu T, Zheng H, Jing Y, et al. Comparison of discectomy versus sequestrectomy in lumbar disc herniation: A meta-analysis of comparative studies. PLoS One. 2015;10(3):e0121816.

8. Fakouri B, Shetty NR, White TCH. Is Sequestrectomy a Viable Alternative to Microdiscectomy? A Systematic Review of the Literature. Clin Orthop Relat Res. 2015;473(6):1957-1962.

9. Azarhomayoun A, Chou R, Shirdel S, Lakeh MM, Vaccaro AR, RahimiMovaghar V. Sequestrectomy versus conventional microdiscectomy for the treatment of a lumbar disc herniation: A systematic review. Spine. 2015;40(24):E1330-1339.

10. Aydin Y, Ziyal IM, Duman H, Türkmen CS, Başak M, Ahin Y. Clinical and radiological results of lumbar microdiskectomy technique with preserving of ligamentum flavum comparing to the standard microdiskectomy technique. Surg Neurol. 2002;57(1):5-13

11. Özay R, Ogur T, Durmaz HA, Turkoglu E, Caglar YS, Sekerci Z, et al. Revisiting Ligament-Sparing Lumbar Microdiscectomy: When to Preserve Ligamentum Flavum and How to Evaluate Radiological Results for Epidural Fibrosis. World Neurosurg. 2018;114:e378-387.

12. Zanoli G, Strömqvist B, Jönsson B. Visual analog scales for interpretation of back and radicular pain intensity in patients operated for degenerative lumbar spine disorders. Spine (Phila Pa 1976). 2001;26(21):23752380.

13. Fairbank JCT, Pynsent PB. The oswestry disability index. Spine (Phila Pa 1976). 2000;25(22):2940-2952

14. Macnab I. Negative disc exploration. An analysis of the causes of nerve-root involvement in sixty-eight patients. J Bone Joint Surg Am. 1971;53(5):891-903.

15. Yong-Hing K, Reilly J, Kirkaldy-Willis WH. The ligamentum flavum. Spine (Phila Pa 1976). 1976; 1(4):226-234.

16. Nachemson AL, Evans JH. Some mechanical properties of the third human lumbar interlaminar ligament (ligamentum flavum). J Biomech. 1968;1(3):211-220.

17. Ozer AF, Oktenoglu T, Sasani M, Bozkus $\mathrm{H}$, Canbulat N, Karaarslan E, et al. Preserving the ligamentum flavum in lumbar discectomy: A new technique that prevents scar tissue formation in the first 6 months postsurgery. Neurosurgery. 2006 ;59(1 Suppl 1):ONS126-133;

18. Yüce İ, Kahyaoğlu O, Çavuşoğlu H, Aydın Y. Surgical outcome and efficacy of lumbar microdiscectomy technique with preserving of ligamentum flavum for recurrent lumbar disc herniations. J Clin Neurosci. 2019;63:43-47.

19. Kim Y-K, Kang D, Lee I, Kim S-Y. Differences in the Incidence of Symptomatic Cervical and Lumbar Disc Herniation According to Age, Sex and National Health Insurance Eligibility: A Pilot Study on the Disease's Association with Work. Int J Environ Res Public Health. 2018;15(10):2094.

20. Kast E, Oberle J, Richter HP, Börm W. 
Success of simple sequestrectomy in lumbar spine surgery depends on the competence of the fibrous ring a prospective controlled study of 168 patients. Spine (Phila $\mathrm{Pa}$ 1976). 2008;33(14):1567-1571.

21. Fakouri B, Patel V, Bayley E, Srinivas S. Lumbar microdiscectomy versus sequesterectomy/free fragmentectomy: A long-term $(>2 y)$ retrospective study of the clinical outcome. J Spinal Disord Tech. 2011;24(1):6-10.

22. Baek GS, Kim YS, Lee MC, Song JW, Kim SK, Kim IH. Fragmentectomy versus conventional microdiscectomy in singlelevel lumbar disc herniations: Comparison of clinical results and recurrence rates. $\mathrm{J}$ Korean Neurosurg Soc. 2012;52(3):210214.

23. Kotil K, Köksal NS, Kayaci S. Long term results of lumbar sequestrectomy versus aggressive microdiscectomy. J Clin Neurosci. 2014 Oct;21(10):1714-1718.

24. Shamji MF, Bains I, Yong E, Sutherland G, Hurlbert RJ. Treatment of herniated lumbar disk by sequestrectomy or conventional diskectomy. World Neurosurg. 2014;82(5):879-883.

25. Thomé C, Barth M, Scharf J, Schmiedek P. Outcome after lumbar sequestrectomy compared with microdiscectomy: a prospective randomized study. J Neurosurg Spine. 2005;2(3):271-278.
26. Carragee EJ, Spinnickie AO, Alamin TF, Paragioudakis S. A prospective controlled study of limited Versus subtotal posterior discectomy: Short-term outcomes in patients with herniated lumbar intervertebral discs and large posterior anular defect. Spine (Phila Pa 1976). 2006;31(6):653-657.

27. Kast E, Mohr K, Richter H-P, Börm W. Results of simple fragment excision in lumbar disc surgery. Orthopade. 2005;34(9):931-937

28. Schick U, Elhabony R. Prospective comparative study of lumbar sequestrectomy and microdiscectomy. Minim Invasive Neurosurg. 2009;52(4):180-185.

29. Boyaci S, Aksoy K. Long-term clinical outcome of the lumbar microdiscectomy and fragmentectomy: A prospective study. Neurosurg Q. 2016;26(2):109-115

30. Barth M, Weiss C, Thomé C. Two-year outcome after lumbar microdiscectomy versus microscopic sequestrectomy - Part 1: Evaluation of clinical outcome. Spine (Phila Pa 1976). 2008;33(3):265-272. 